\title{
Identification and Evaluation of Chickpea Germplasm for Tolerance to Heat Stress
}

\author{
Hari D. Upadhyaya,^ N. Dronavalli, C. L. L. Gowda, and Sube Singh
}

\begin{abstract}
Global warming and extreme temperatures are predicted in the future, hence identification of appropriate varieties that could adapt to such changes is imperative for sustaining crop productivity. Thirty-five early maturing chickpea (Cicer arietinum L.) germplasm accessions were evaluated for their tolerance to heat stress. Plant traits such as plant width, flowering duration, days to maturity, pod number, seed weight, grain yield and per-day productivity were affected under heat stress. Genotypes differed in their sensitivity to heat stress, and the yield loss among genotypes varied from 10 to $15 \%$ of potential yield for every degree increase in temperature beyond the optimum temperature range. Multiple regression analysis indicated that the plant trait expression can be predicted accurately for the assumed change in climate on the basis of mean temperature, daylength, duration of bright sunshine, incident solar radiation, relative humidity, wind velocity, and potential evaporation. Mitigation of heat stress by irrigation and application of additional nitrogen to the crop resulted in sustaining the potential yield (up to 80\%). ICC 14346 showed high tolerance to heat stress and could be used as a parent in crop improvement research. ICC 5597, ICC 5829, ICC 6121, ICC 7410, ICC 11916, ICC 13124, ICC 14284, ICC 14368, and ICC 14653 were heat stress tolerant, responsive to irrigation and nitrogen management, and consistently high yielding (>1400 $\left.\mathrm{kg} \mathrm{ha}^{-1}\right)$ compared with the control ICCV 92944 (1333 $\left.\mathrm{kg} \mathrm{ha}^{-1}\right)$.
\end{abstract}

International Crops Research Institute for the Semi-Arid Tropics (ICRISAT), Patancheru PO, Hyderabad, Andhra Pradesh 502 324, India. Received 12 Jan. 2011. ^Corresponding author (h.upadhyaya@cgiar.org).

Abbreviations: $\sigma^{2}$ g, genotypic variance; $\sigma^{2}$ ge, genotype $\times$ environment interaction variance; APB, apical primary branches; ASB, apical secondary branches; $\mathrm{BPB}$, basal primary branches; $\mathrm{BSB}$, basal secondary branches; DAS, days after sowing; DBS, duration of bright sunshine; DF, days to flowering; DL, daylength; DM, days to maturity; FD, flowering duration (days); $h^{2} b$, heritability in broad sense; ISR, intensity of solar radiation; PE, potential evaporation; $\mathrm{PH}$, plant height; $\mathrm{PN}$, pods plant $^{-1}$; PROD, productivity; PW, plant width; REML, residual (or restricted) maximum likelihood; RH, relative humidity; SI, spring irrigated; SP, seeds pod $^{-1}$; STI, stress tolerance index; SW, 100-seed weight; TB, tertiary branches; Tmax, diurnal temperature maximum; Tmean, diurnal temperature mean; Tmin, diurnal temperature minimum; WI, winter irrigated; WR, winter rainfed; WV, wind velocity; YKGH, grain yield.
A GRICULTURE remains highly sensitive to climate fluctuations, the chief cause of interannual variability of production in many regions and a continuing source of disruption to ecosys- tem productivity (Ferris, 1999). Greenhouse gases are predicted to increase the temperature of the globe at $\sim 0.1^{\circ} \mathrm{C}$ per decade, and these higher global temperatures may have nonlinear and increasingly negative effects on agriculture, necessitating appro- priate adaptation responses (Howden et al., 2007). Hence, it has become critical to identify and evaluate options for adapting crops to climate change in coming decades. Future crop cultivars will need to maintain or even be higher yielding, under the expected climate changes. Thus future crops and cultivars need resistance to multiple abiotic and biotic stresses in the context of sustainable production and response to nutrient management and irrigation
Published in Crop Sci. 51:2079-2094 (2011).
doi: 10.2135/cropsci2011.01.0018
Published online 12 July 2011.
(C) Crop Science Society of America | 5585 Guilford Rd., Madison, WI 53711 USA
All rights reserved. No part of this periodical may be reproduced or transmitted in any form or by any means, electronic or mechanical, including photocopying, recording, or any information storage and retrieval system, without permission in writing from the publisher. Permission for printing and for reprinting the material contained herein has been obtained by the publisher. 
(Toker and Yadav, 2010). Adaptation research undertaken now can help decisions by farmers, agribusiness, and policymakers, with implications over a range of time frames from short-term tactical to long-term strategic (Easterling et al., 2007). The heat tolerance mechanism, like that of drought tolerance, could be actual homeostasis to high temperature or heat avoidance by maturing early before the temperature rises. Altering inputs such as varieties or species to those with more appropriate thermal time and vernalization requirements and/or with increased resistance to heat shock and drought; altering fertilizer usage to maintain grain and fruit yield and quality consistent with the prevailing climate; and altering irrigation and other water management practices are some of the potential ways to deal with the projected climatic and atmospheric changes (Travasso et al., 2006), along with altering the timing and location of cropping activities (Howden et al., 2007).

Chickpea (Cicer arietinum L.) is an important food legume, ranking third among the world's pulse crops (FAO, 2008). It is grown in 45 countries on an area of about 11.55 million hectares, annually producing about $8.78 \mathrm{Tg}$, and with a productivity of $760 \mathrm{~kg} \mathrm{ha}^{-1}$. The Indian subcontinent (India, Pakistan, Myanmar, Bangladesh, and Nepal) contributes about $72 \%$ of the world's chickpea production. Chickpea is also cultivated in Eastern Africa, the Mediterranean, West Asian countries, Australia, Southern Europe, and the Americas. Chickpea is a rich source of quality protein to the predominantly vegetarian population in India and for a majority of the population in South Asian and Near-East countries. In the developed countries chickpea is regarded as a health food. It is devoid of any antinutritional factors except oligosaccharides (that cause flatulence), which is, however, inactivated by cooking (Williams and Singh, 1987).

In the last four decades, the area under chickpea has declined and been replaced by crops such as wheat (Triticum aestivum $\mathrm{L}$.), which produce higher and more stable yields under high input irrigated environments (Kelly and Parthasarathy, 1994). As a result, chickpea has been relegated to poor and marginal lands with lower and unstable productivity. About $90 \%$ of chickpea production occurs on residual soil moisture under rainfed conditions (Sharma and Jodha, 1984; Kumar and van Rheenan, 2000), where terminal drought and heat stresses are major limitations to higher productivity (Johansen et al., 1997). These rainfed regions are threatened by climatic changes accompanied by erratic rainfall patterns and low dew precipitation-the dew that is highly beneficial to chickpea for preflowering biomass production (Basu et al., 2009).

Chickpea is essentially a cool season crop and is sensitive to heat stress. In recent years the crop has also been experiencing abnormally high temperature $\left(>35^{\circ} \mathrm{C}\right)$ during the reproductive phase (Basu et al., 2009). High temperature adversely affects seed germination, photosynthesis, membrane stability, nutrient absorption, protoplasmic movement, hormone activity, fertilization and pod set, pod development, seed set, and seed quality (Wahid et al., 2007). Heat stress is a major factor limiting growth of cool season crops in the transitional and warm climatic regions ( $\mathrm{Xu}$ and Huang, 2001). The heat tolerance capacity varies with cultivars and could involve changes in both morphological and physiological traits (Wu and Huff, 1983; Huang and Gao, 2000), and therefore heat- and/or drought-tolerant genotypes could be of great promise in this direction.

Apart from increasing the genetic yield potential, extending chickpea cultivation beyond the cool winter period, for example, to the spring season (15 January onward in southern India) when temperatures would be warmer, can contribute to increased production for meeting the consumer demand. However, currently there are no recognized cultivars or landraces that could grow well in the spring season, successfully tolerating the high day, night temperatures $\left(>35^{\circ} \mathrm{C},>25^{\circ} \mathrm{C}\right)$. Tolerance to high temperature is also important in view of global warming, whick will have an adverse impact on agriculture, including chickpea in the areas where it is presently cultivated. Therefore, most breeding programs aim to develop early-maturing cultivars whose maturity period matches with the available soil moisture and duration of optimum weather conditions available for the crop.

Phenology of the crop has an immense influence on productivity and stability. Appropriate time to flowering is a major component of crop adaptation, particularly in environments where the growing season is restricted by terminal drought and high temperature (Subbarao et al., 1995). Early flowering and maturity combined with other desirable plant traits can prolong the reproductive phase in various target environments. This implies that chickpea needs to be improved for adaptation to high-temperature environments, irrigation, and better nutrition. It is critical to identify germplasm lines that tolerate heat stress and respond to better management. The objective of this study was to identify heat-tolerant chickpea genotypes on the basis of their grain yield and associated characters for the benefit of chickpea breeders and to identify a minimum number of predictor variables for the model that explains variation in the important traits.

\section{MATERIALS AND METHODS}

Thirty-five early maturing germplasm accessions selected from clusters of the chickpea core collection (Upadhyaya et al., 2001) that mature in the available duration at Patancheru, India, were selected for evaluation. Of these, 17 were small-seeded $(100-$ seed weight $<20 \mathrm{~g})$ desi type, 8 were medium-seeded (21-30 g) desi type, 7 were large-seeded (31-50 g) kabuli type, and 3 were extra-large-seeded (>50 g) kabuli type (Table 1). An early-maturing medium-seed-size cultivar, ICCV 92944, which was reported to be heat tolerant (Gaur et al., 2007; Basu et al., 2009), was used as the control cultivar. Experiments were conducted sequentially for $3 \mathrm{yr}$ at Patancheru $\left(18^{\circ} \mathrm{N}, 78^{\circ} \mathrm{E}\right.$, 
Table 1. Country of origin and biological status of early maturing chickpea (Cicer arietinum L.) germplasm accessions included in the study.

\begin{tabular}{|c|c|c|c|c|c|c|c|}
\hline Germplasm line & Identity & Country of origin & Biological status & Germplasm line & Identity & Country of origin & Biological status \\
\hline Desi types & & & & ICC 14649 & RSW 44 & India & Landrace \\
\hline ICC 5597 & $4-62$ & Russia \& CIS & Landrace & ICC 14653 & RSW 47 & India & Landrace \\
\hline ICC 5829 & K 1180 & Iran & Landrace & ICC 16347 & ICCV 88501 & ICRISAT & Breeding line \\
\hline ICC 6121 & JG 112 & India & Landrace & ICC 16348 & ICCV 88502 & ICRISAT & Breeding line \\
\hline ICC 7410 & T70 B & India & Landrace & ICC 16349 & ICCV 88503 & ICRISAT & Breeding line \\
\hline ICC 11916 & PI359618 & Iran & Landrace & ICC 17451 & W6 17593 & Mexico & Landrace \\
\hline ICC 12426 & ICCC 37 & India & Released cultivar & ICC 18892 & IG 5997 & Tunisia & Landrace \\
\hline ICC 12532 & RFG 10 & Ethiopia & Landrace & ICC 19641 & PI 518252 & India & Landrace \\
\hline ICC 12670 & RFG 74-1 & Ethiopia & Landrace & ICC 19645 & PI 518257 & India & Landrace \\
\hline ICC 13044 & PI359300 & India & Landrace & & Kabuli types & & \\
\hline ICC 13124 & PI450831 & India & Landrace & ICC 14197 & Garbanzo & Mexico & Breeding line \\
\hline ICC 13839 & RFG 69 & Ethiopia & Landrace & ICC 14205 & 125-TBB & Mexico & Landrace \\
\hline ICC 13925 & RAM-36-1 & Ethiopia & Landrace & ICC 17450 & W6 17591 & Mexico & Landrace \\
\hline ICC 14284 & $\mathrm{RC} 97$ & India & Landrace & ICC 17452 & W6 17594 & Mexico & Landrace \\
\hline ICC 14293 & $\mathrm{RC} 110$ & India & Landrace & ICC 17456 & W6 17599 & Mexico & Landrace \\
\hline ICC 14345 & BG 273 & India & Breeding line & ICC 17458 & W6 17603 & Mexico & Landrace \\
\hline ICC 14346 & BG 274 & India & Breeding line & ICC 17459 & W6 17604 & Mexico & Landrace \\
\hline ICC 14368 & P478WR & India & Breeding line & ICC 18591 & W6 17607 & Mexico & Landrace \\
\hline ICC 14648 & RSW 43 & India & Landrace & ICCV 92944 (Control) & Yezin 6 & India & Released cultivar \\
\hline
\end{tabular}

545 meters above sea level [m.a.s.1.]), India during the years 2007-2008, 2008-2009, and 2009-2010.

Three planting regimes were selected: (i) winter planting (last week of October) with supplemental irrigation (WI), to assess the yield potential of the genotypes; (ii) winter planting under rainfed receding soil moisture situation (WR), which is the standard cropping practice; and (iii) spring planting (last week of January or early February of succeeding year) with protective irrigation (SI), to assess genotype response to heat stress. The potential yield of a genotype can be assessed as its output under ideal crop management and stress-free conditions. Adverse climatic stress is a limiting factor. In this study we used the WI regime to estimate the potential yield of the chickpea accessions, so as to make a critical comparison of performance under ideal stress-free and adverse high-stress environments. In tropical climates excess of radiation and high temperatures are often the most limiting factors affecting plant growth and final crop yield (Wahid et al., 2007). The climate factors play a critical role in the rate of photosynthesis, canopy transpiration, and surface evaporation, affecting the water balance and physiology of the plants. Therefore meteorological data for the entire crop period starting from the 43rd standard wk (last week of October) to the 15th standard wk (9-15 April) of the succeeding year, corresponding to crop weeks 1 to 15 for the winter crop and 1 to 13 for the spring crop, were recorded (Table 2). Data was recorded for diurnal temperature maximum (Tmax), minimum (Tmin), and daily mean (Tmean) in ${ }^{\circ} \mathrm{C}$, mean intensity of solar radiation (ISR, in $\mathrm{Mj} / \mathrm{m}^{2}$ ), rainfall (in $\mathrm{mm}$ ), relative humidity ( $\mathrm{RH}$, in \%), duration of bright sunshine (DBS, in hours), potential evaporation ( $\mathrm{PE}$, in $\mathrm{mm}$ ), daylength ( $\mathrm{DL}$, in hours), as well as wind velocity (WV, in $\mathrm{km} \mathrm{h}^{-1}$ ).

The experiments were conducted in the randomized complete block design using two replications with a plot size of $4.8 \mathrm{~m}^{2}$ for each entry. All the experiments were planted in vertisols using a spacing of $30 \mathrm{~cm}$ between rows and $10 \mathrm{~cm}$ between plants. Uniform depths of sowing and optimum plant population levels were maintained and received a common presowing irrigation. For WI crop, two irrigations $(5 \mathrm{~cm}$ of water per irrigation), one at preflowering and the other during active flowering and/or grain-filling period were given during 2007-2008 and 2008-2009, while a single irrigation at $17 \mathrm{~d}$ after sowing (DAS) was given during 2009-2010, depending on the crop requirement. For the SI crop, depending on crop requirement, three irrigations, at 32, 47, and 53 DAS during 2008; four irrigations at 22, 39, 54, and 66 DAS during 2009; and five irrigations at $24,39,52,65$, and 73 DAS in 2010 were

Table 2. Weather data for winter and spring seasons over years (2007-2008 to 2009-2010) for the cropping period (range for each parameter) at ICRISAT, Patancheru, India

Climatic factors Season 2007-2008 2008-2009 2009-2010

Maximum temperature $\left({ }^{\circ} \mathrm{C}\right)$ Winter $28.1-31.8 \quad 28.1-31.4 \quad 26.9-31.1$

\begin{tabular}{lcccc} 
Maximum temperature $\left({ }^{\circ} \mathrm{C}\right)$ & Winter & $28.1-31.8$ & $28.1-31.4$ & $26.9-31.1$ \\
& Spring & $28.8-37.5$ & $31.9-39.8$ & $27.5-40.2$ \\
Minimum temperature $\left({ }^{\circ} \mathrm{C}\right)$ & Winter & $9.8-19.0$ & $11.5-17.9$ & $12.6-21.8$ \\
& Spring & $13.6-21.0$ & $11.7-24.9$ & $13.0-25.6$ \\
Mean temperature $\left({ }^{\circ} \mathrm{C}\right)$ & Winter & $19.0-24.2$ & $20.3-24.3$ & $20.2-26.0$ \\
& Spring & $21.8-29.3$ & $21.8-32.4$ & $20.3-32.9$ \\
Rainfall $(\mathrm{mm})$ & Winter & 36.8 & 26.6 & 90.6 \\
& Spring & 225.2 & 33.6 & 3.0 \\
Relative humidity $(\%)$ & Winter & $27.4-58.3$ & $21.0-59.1$ & $28.3-59.3$ \\
\multirow{2}{*}{ Evaporation $(\mathrm{mm})$} & Spring & $17.1-56.4$ & $16.4-34.4$ & $19.8-34.4$ \\
& Winter & $3.67-5.44$ & $3.14-6.43$ & $4.06-11.10$ \\
Mean solar radiation $\left(\mathrm{Mj} / \mathrm{m}^{2}\right)$ & Winter & $14.6-18.5$ & $11.9-19.9$ & $12.3-18.6$ \\
& Spring & $13.5-23.0$ & $17.2-21.7$ & $16.0-23.3$ \\
Bright sunshine $(\mathrm{h})$ & Winter & $6.1-10.2$ & $4.8-10.3$ & $5.0-10.5$ \\
& Spring & $4.0-10.6$ & $7.0-10.5$ & $6.6-10.2$ \\
Wind velocity $\left(\mathrm{km} \mathrm{h}{ }^{-1}\right)$ & Winter & $3.1-6.8$ & $2.9-7.7$ & $2.2-8.9$ \\
& Spring & $4.6-7.6$ & $3.9-6.5$ & $4.7-7.7$
\end{tabular}

Day length (h) Winter $\quad 11.14-11.16 \quad 11.14-11.15 \quad 11.13-11.15$ Spring 11.62-11.74 11.66-11.81 11.80-11.88 
given to maintain the optimum soil moisture. The experiments received fertilizer at $16 \mathrm{~kg} \mathrm{~N}$ and $46 \mathrm{~kg} \mathrm{P}_{2} \mathrm{O}_{5} \mathrm{ha}^{-1}$ in the form of diammonium phosphate, as basal dose. Other crop husbandry practices were followed as per recommendations. Five representative plants were selected randomly in each plot to record observations on plant height $(\mathrm{PH}, \mathrm{cm})$, plant width $(\mathrm{PW}, \mathrm{cm})$, and number of basal primary branches (BPB), apical primary branches (APB), basal secondary branches (BSB), apical secondary branches (ASB), tertiary branches (TB), pods plant ${ }^{-1}(\mathrm{PN})$, and seeds $\operatorname{pod}^{-1}$ (SP). The data on days to $50 \%$ flowering (DF), flowering duration (FD), days to maturity (DM), 100-seed weight (SW, g), grain yield (YKGH, $\mathrm{kg} \mathrm{ha}^{-1}$ ), and productivity (PROD, $\mathrm{kg} \mathrm{ha}^{-1} \mathrm{~d}^{-1}$ ) were recorded on plot basis following IBPGR, ICRISAT, and ICARDA (1993) descriptors. For the purpose of summarizing results and discussion, the traits studied were grouped into three broad categories on the basis of the life cycle of the chickpea plant (Gowda et al., 2011).

Vegetative traits: plant height, plant width, basal primary branches, apical primary branches, basal secondary branches, apical secondary branches, and tertiary branches;

Reproductive traits: days to 50\% flowering, flowering duration, days to maturity;

Yield and yield component traits: pods plant ${ }^{-1}$, seeds pod ${ }^{-1}$, 100-seed weight, grain yield, and productivity.

Data for each experiment was analyzed separately for each environment and the genotypic variance $\left(\sigma^{2} \mathrm{~g}\right)$ estimated using residual (or restricted) maximum likelihood (REML; Patterson and Thompson, 1971) in GenStat 12 (http://www.vsni.co.uk). Pooled analysis for $3 \mathrm{yr}$ was performed separately for each regime (WI, SI, WR), the two irrigated regimes, and all three regimes using REML (DerSimonian and Laird, 1986; Hardy and Thompson, 1996; Whitehead, 2002). Genotypes were considered random and seasons as fixed. Variance due to genotypes, genotypes $\times$ environment (season) interaction $\left(\sigma^{2}\right.$ ge), and their standard errors were estimated and significance determined. The differences among seasons were tested using Wald (1943) statistics. Best linear unbiased predictors (Schönfeld and Werner, 1986) were worked out for all quantitative traits. The heritability in broad sense $\left(h^{2} b\right)$ was estimated for each environment separately and for pooled data. Correlations between agronomic traits and environmental factors were calculated separately. The stress tolerance index (STI) was calculated following the method of Fisher and Maurer (1978). Multiple regression analysis was performed using data on WI and SI to determine the influence of independent or predictor (environmental factors) variables on dependant variables, for example, yield and other important agronomic traits. Analysis of variance (ANOVA) was performed separately, and significance of predictor variables was determined for each of the agronomic traits, considering the $F$ value at $P=0.05$. The value of predictor variables was calculated for vegetative and reproductive or yield traits separately. Thus number of predictor variables differed with the type of traits in the ANOVA and further analyses. The significant $(P \geq 0.05)$ variables were considered for stepwise multiple regression. This is the most sophisticated and rigorous statistical procedure, in which each variable is entered in sequence and its value assessed. If adding the variable contributes to the model then it is retained. At the same time, all other variables in the model are retested to examine whether they are still contributing to the model. Thus, this method ensures that the smallest possible set of predictor variables are included in the model. The parameters (constant, b) were estimated and their significance tested using the $t$ test. The variables with significant $b$ values were finally selected for inclusion in the model. $R$-square $\left(R^{2}\right)$, which indicates the proportion of the variance in the dependant variable that is accountable by the model, was estimated. Since $R^{2}$ tends to overestimate the success of the model, adjusted $R^{2}$, which takes into account the number of variables in the model and number of observations on which the model is based and thus provides the most useful measure of success of the model, was calculated.

\section{RESULTS AND DISCUSSION Weather Parameters}

The range of variation for different weather parameters (Table 2) is summarized below.

\section{Daylength}

The DL (sunrise to sunset) during the cropping period was almost the same, varying only for a few minutes between years because of a few days difference in planting dates. It varied from 11.14 to $11.16 \mathrm{~h}$ during the winter and 11.62 to $11.88 \mathrm{~h}$ during the spring season.

\section{Diurnal Temperature}

The temperature did not show much variation over the years during the winter season, except for Tmin, which varied slightly (Table 2). The Tmax varied from 26.9 to $31.8^{\circ} \mathrm{C}$ over the years in winter while the Tmin varied widely, from 9.8 to $19.0^{\circ} \mathrm{C}$ during $2007-2008$, from 11.5 to $17.9^{\circ} \mathrm{C}$ during $2008-2009$, and from 12.6 to $21.8^{\circ} \mathrm{C}$ during 2009-2010. For the spring season Tmax varied from 28.8 to 37.5 (2007-2008), from 31.9 to 39.8 (2008-2009), and from 27.5 to $40.2^{\circ} \mathrm{C}$ during 2009-2010. The Tmin varied from 13.6 to 21.0 (2007-2008), from 11.7 to 24.9 (2008-2009), and from 13.0 to 25.6 (2009-2010). The Tmean varied from 19.0 to $26.0^{\circ} \mathrm{C}$ during winter and 20.3 to $32.9^{\circ} \mathrm{C}$ during spring. The difference in mean temperature between winter and spring sowing varied from 2.8 to $5.1^{\circ} \mathrm{C}$ in $2007-2008$, from 1.5 to $8.1^{\circ} \mathrm{C}$ in $2008-2009$, and from 0.1 to $6.9^{\circ} \mathrm{C}$ in $2009-2010$. The difference was low $\left(<5^{\circ} \mathrm{C}\right)$ before onset of flowering and thereafter increased rapidly up to $12^{\circ} \mathrm{C}$, before physiological maturity (Fig. 1).

\section{Rainfall}

Rainfall is critical for crop productivity, especially in stress situations. The WR crop suffered moisture stress owing to lack of rainfall from preflowering stage to harvest in 2007-2008 but fared better with rainfall of $26.6 \mathrm{~mm}$ at preflowering stage (25-40 DAS) during 2008-2009 and a welldistributed rainfall $(44.2 \mathrm{~mm}$ before flowering and $46.4 \mathrm{~mm}$ during pod development) during 2009-2010. Thus rainfall improved the WR crop grain yield across years, from $970 \mathrm{~kg} \mathrm{ha}^{-1}$ in $2007-2008$ to $1263 \mathrm{~kg} \mathrm{ha}^{-1}$ in 2008-2009 

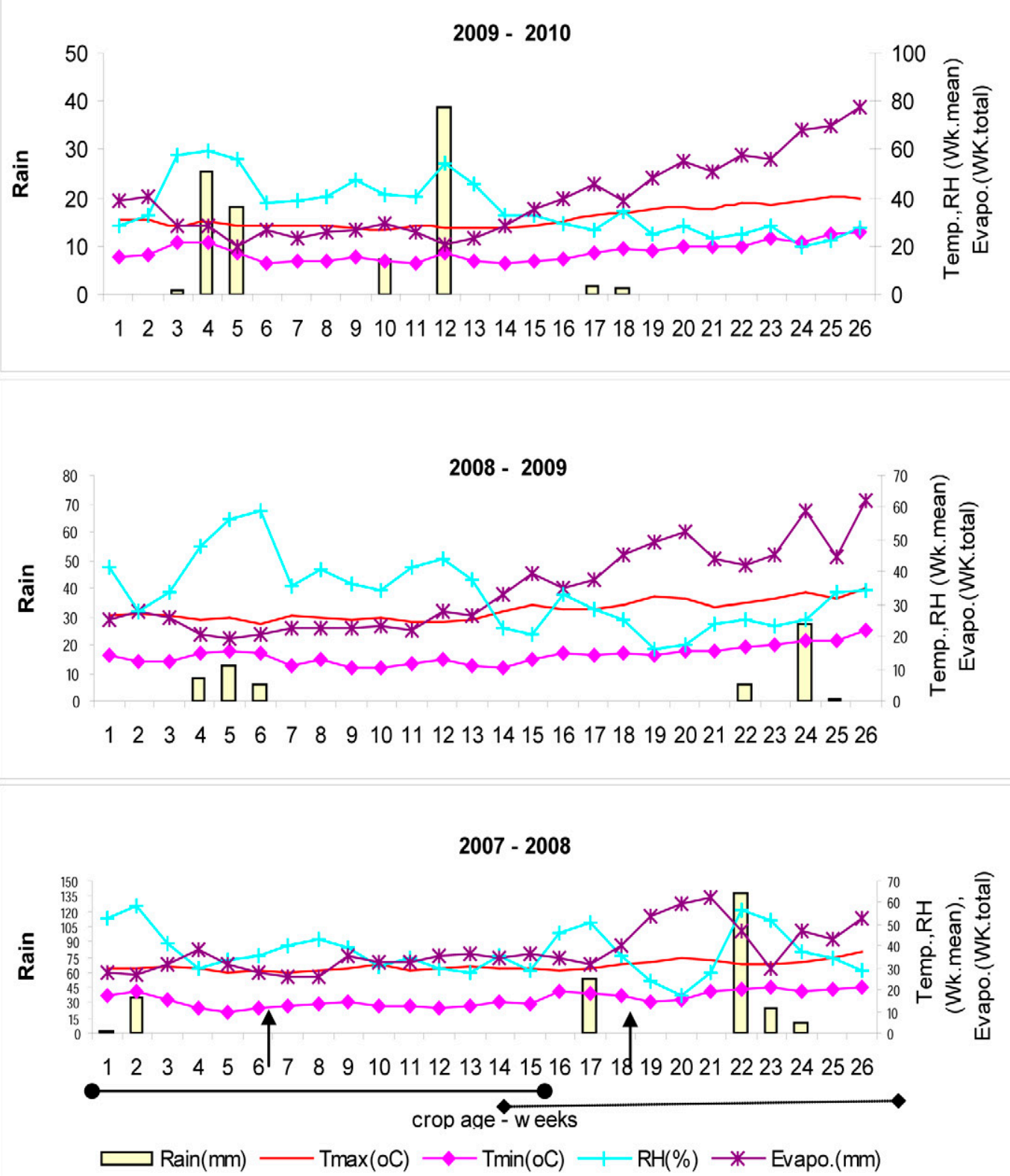

Figure 1. Weather data from standard wk 43 to 16 (succeeding year). Vertical arrows indicate beginning of flowering. Winter crop period (22 Oct. to 5 Feb.); spring crop period (27 Jan. to 25 Apr.). $\mathrm{RH}$, relative humidity.

and $1352 \mathrm{~kg} \mathrm{ha}^{-1}$ 2009-2010 (Fig. 1). The SI crop also benefited from rainfall received at 25 DAS $(52.2 \mathrm{~mm})$ and 60 to 80 DAS (173.0 $\mathrm{mm}$ during 2007-2008 and $33.6 \mathrm{~mm}$ during 2008-2009), apart from the protective irrigations.

\section{Relative Humidity}

The RH (at 14th h of the day) varied from 21 to $40 \%$ and 16 to $34 \%$, in all the 3 yr during winter and spring respectively, rising up to 56 to $59 \%$ during rainy weeks.

\section{Potential Evaporation}

The PE varied from 3.14 to $11.10 \mathrm{~mm}$ and 4.06 to $11.10 \mathrm{~mm}$ in all $3 \mathrm{yr}$ during winter and spring, respectively. The mean evaporation was very high during spring $(6.3-7.5 \mathrm{~mm})$ compared with winter $(4.0-4.6 \mathrm{~mm})$.

\section{Intensity of Solar Radiation}

The ISR varied from 11.9 to $19.9 \mathrm{Mj} / \mathrm{m}^{2}$ during winter and from 13.5 to 23.3 for spring. The mean ISR was also high (by 2 to $4 \mathrm{Mj} / \mathrm{m}^{2}$ ) for the spring.

\section{Duration of Bright Sunshine}

The DBS varied between years and between winter and spring seasons (Table 2). The DBS for spring was longer by 45 min during 2009-2010 only.

\section{Wind Velocity}

The WV varied between 2.2 and 8.9 and 3.9 and $7.7 \mathrm{~km} \mathrm{~h}^{-1}$ respectively for winter and spring seasons over the years. The mean WV for spring was higher by $\sim 1.5 \mathrm{~km} \mathrm{~h}^{-1}$. 
Table 3. Genotypic $\left(\sigma^{2} g\right)$ and genotype $\times$ environment $\left(\sigma^{2}\right.$ ge) variances of early maturing chickpea (Cicer arietinum L.) germplasm evaluated in winter-irrigated (WI), winter-rainfed (WR), and spring-irrigated (SI) environments during 2007-2008, 20082009, and 2009-2010 at Patancheru, India.

\begin{tabular}{|c|c|c|c|c|c|c|c|c|c|c|}
\hline Trait $^{\dagger}$ & $\begin{array}{c}\sigma^{2} \mathrm{~g} \\
\text { pooled, } \\
\text { three } \\
\text { seasons } \\
\text { (WI) }\end{array}$ & $\begin{array}{c}\sigma^{2} g \\
\text { pooled, } \\
\text { three } \\
\text { seasons } \\
\text { (SI) }\end{array}$ & $\begin{array}{c}\sigma^{2} g \\
\text { pooled, } \\
\text { three } \\
\text { seasons } \\
\text { (WR) }\end{array}$ & $\begin{array}{c}\sigma^{2} \mathrm{~g} \\
\text { pooled, } \\
\text { six } \\
\text { seasons } \\
(\mathrm{WI}+\mathrm{SI})\end{array}$ & $\begin{array}{c}\sigma^{2} \mathrm{~g} \\
\text { pooled, } \\
\text { nine } \\
\text { seasons } \\
\text { (WI + SI + WR) }\end{array}$ & $\begin{array}{c}\sigma^{2} \text { ge } \\
\text { pooled, } \\
\text { three } \\
\text { seasons } \\
\text { (WI) }\end{array}$ & $\begin{array}{c}\sigma^{2} \text { ge } \\
\text { pooled, } \\
\text { three } \\
\text { seasons } \\
\text { (SI) }\end{array}$ & $\begin{array}{c}\sigma^{2} \text { ge } \\
\text { pooled, } \\
\text { three } \\
\text { seasons } \\
\text { (WR) }\end{array}$ & $\begin{array}{c}\sigma^{2} \text { ge } \\
\text { pooled, } \\
\text { six } \\
\text { seasons } \\
(\mathrm{WI}+\mathrm{SI})\end{array}$ & $\begin{array}{c}\sigma^{2} \mathrm{ge} \\
\text { pooled, } \\
\text { nine } \\
\text { seasons } \\
(\mathrm{WI}+\mathrm{SI}+\mathrm{WR})\end{array}$ \\
\hline$\overline{\mathrm{DF}}$ & $16.17^{\star \star}$ & $7.91^{\star \star}$ & $10.6^{\star *}$ & $11.47^{\star *}$ & $11.80^{* *}$ & $13.76^{\star *}$ & $7.07^{* *}$ & $9.13^{\star \star}$ & $9.57^{\text {** }}$ & $8.79^{* *}$ \\
\hline FD & $6.68^{*}$ & 0.56 & $6.26^{*}$ & 1.93 & $133^{\star *}$ & $10.14^{\star *}$ & $9.67^{\star *}$ & $7.42^{* *}$ & $10.83^{\star *}$ & $52^{*}$ \\
\hline DM & $17.62^{\star \star}$ & $18.35^{\star \star}$ & $13.96^{* *}$ & $19.20^{* *}$ & $19.04^{\star *}$ & $9.81^{* *}$ & $8.46^{\star \star}$ & $16.84^{\star *}$ & $9.17^{\star *}$ & $9.83^{\star \star}$ \\
\hline $\mathrm{PH}$ & $42.58^{\star \star}$ & $35.81^{* *}$ & $25.77^{\star \star}$ & $37.71^{\star \star}$ & $33.63^{* *}$ & $14.20^{\star \star}$ & $4.27^{\star \star}$ & $7.71^{\star \star}$ & $9.23^{\star *}$ & $8.89^{\star \star}$ \\
\hline PW & 0.01 & $2.98^{\star}$ & $2.86^{\star}$ & $3.94^{*}$ & $3.29^{\star \star}$ & $19.91^{\star *}$ & $4.78^{\star \star}$ & 0.76 & $10.42^{\star *}$ & $7.26^{\star *}$ \\
\hline BPB & $0.12^{*}$ & $0.18^{\star *}$ & $0.14^{*}$ & $0.13^{\star *}$ & $0.13^{\text {** }}$ & 0.08 & 0.06 & 0.04 & $0.10^{* *}$ & $0.08^{* *}$ \\
\hline APB & 0.05 & 0.12 & 0.1 & 0.07 & $0.12^{\text {** }}$ & $0.40^{* *}$ & $0.64^{\star *}$ & $0.41^{* *}$ & $0.44^{\star *}$ & $0.41^{\text {** }}$ \\
\hline BSB & $0.49^{\text {** }}$ & $0.17^{\star}$ & 0.18 & $0.28^{\star *}$ & $0.27^{\star *}$ & 0.01 & 0.05 & 0.18 & $0.15^{*}$ & $0.13^{*}$ \\
\hline ASB & $1.37^{\star *}$ & $1.16^{\star \star}$ & $1.27^{\star \star}$ & $1.23^{\star *}$ & $1.25^{\star \star}$ & 0.22 & $0.61^{*}$ & 0.45 & $0.6^{\star *}$ & $0.53^{\star \star}$ \\
\hline TB & $0.08^{*}$ & 0.01 & 0.03 & 0.04 & $0.04^{\star \star}$ & 0.06 & $0.15^{\star}$ & 0.03 & $0.15^{\star \star}$ & $0.10^{\star *}$ \\
\hline PN & $222.4^{\star \star}$ & $104^{\star \star}$ & $96.8^{\star \star}$ & $117^{* *}$ & $114.8^{* \star}$ & 42.5 & $86.62^{\star \star}$ & 25.6 & $51.7^{\star \star}$ & $38.8^{\star \star}$ \\
\hline SP & $0.02^{\star \star}$ & $0.01^{\star *}$ & 0.01 & $0.01^{\star *}$ & $0.02^{\star *}$ & $0.01^{*}$ & $0.01^{\star *}$ & 0.01 & $0.01^{\star *}$ & $<0.001$ \\
\hline SW & $185.44^{\star *}$ & $140.5^{\star *}$ & $170.5^{\star \star}$ & $147.37^{\star *}$ & $155.97^{\star \star}$ & $17.1^{\star \star}$ & $20.68^{\star \star}$ & $7.05^{\star \star}$ & $18.34^{\star \star}$ & $14.20^{\star *}$ \\
\hline YKGH & $88790^{\star *}$ & $32733^{\star}$ & 22515 & $46399^{\star *}$ & $41491^{\star \star}$ & 13509 & $53864^{\star \star}$ & 12983 & $39117^{\star \star}$ & $27707^{\star *}$ \\
\hline PROD & $8.33^{\star *}$ & $5.36^{\star *}$ & 3.21 & $5.99^{* *}$ & $5.44^{* *}$ & 1.17 & $6.61^{* *}$ & 1.59 & $4.85^{\text {** }}$ & $3.45^{\text {** }}$ \\
\hline
\end{tabular}

*Significant at $P=0.05$

${ }^{*}$ Significant at $P=0.01$.

${ }^{\dagger} \mathrm{DF}$, days to flowering (no.); FD, days to flowering duration (no.); DM, days to maturity (no.); PH, plant height (cm); PW, plant width (cm); BPB, basal primary branches (no.); APB, apical primary branches (no.); BSB, basal secondary branches (no.); ASB, apical secondary branches (no.); TB, tertiary branches (no.); PN, pods plant ${ }^{-1}$; SP, seeds pod $^{-1}$; SW, 100-seed weight (g); YKGH, grain yield $\left(\mathrm{kg} \mathrm{ha}^{-1}\right)$; PROD, productivity $\left(\mathrm{kg} \mathrm{ha}^{-1} \mathrm{~d}^{-1}\right)$.

The main climatic difference between winter and spring was high temperature, low $\mathrm{RH}$, high $\mathrm{PE}$, high ISR, high WV, and longer DBS during spring. This combination imposes severe heat stress on crops because of the steep increase in transpiration and hinders photosynthesis (Gaur et al., 2007). Correlations among the climate factors that were incidental during the crop period (October to April) were highly significant among the average Tmax, average Tmin, and average Tmean, among themselves as well as with DL, PE, ISR, and WV, and were highly negative with $\mathrm{RH}$. The RH was also negatively correlated with PE, ISR, and DBS. The PE showed high positive correlation with ISR and WV, while ISR had high positive correlation with WV. The Tmax, Tmin, and Tmean have influenced the plant traits in an identical manner, hence only Tmean was considered. Likewise the RH at $1400 \mathrm{~h}$ showed a better association with plant traits than RH at $0700 \mathrm{~h}$.

\section{Adequacy of Environments}

For any multienvironment study, adequacy of selected environments in differentiating the genotypes is important. The Wald statistic that asymptotically follows a $\sigma^{2}$ distribution was used to determine the significance of environments. The Wald statistic was highly significant for grain yield and yield components except SP and for DM and FD among reproductive characters. Among morphological characters the Wald statistic was highly significant for PH, PW, BPB, and APB (data not given). Overall, the high significance of the Wald statistic validates the adequacy of selected environments for differentiating genotypes.

\section{Crop and Genotype Performance}

The genotypic performance across years (seasons) under different planting regimes is summarized below.

\section{Winter Irrigated}

The REML analysis of variance (Table 3 ) indicated highly significant genotypic differences for all traits except APB during 2007-2008; APB and SP during 2008-2009; PW, BPB, ASB, and SP during 2009-2010; and PW and APB in pooled analysis (year-wise data not given). The $\sigma^{2} \mathrm{~g}$ for branching traits and SP was low but highly significant, which may be due to the low error variance. Overall the genetic variability among the genotypes was highly significant for most of the traits.

The trait means for all genotypes (Table 4) indicate that the mean grain yield (pooled) was $1886 \mathrm{~kg} \mathrm{ha}^{-1}$ for winter irrigated (WI), varying from 1693 to 2202 between years. None of the entries were significantly superior to the control ICCV 92944 in any year or overall. However, some entries like ICC 5597, ICC 12426, ICC 14346 (all small seeded), ICC 6121, ICC 7410, and ICC 14284 (all medium seeded) showed consistent superiority in all years, with a mean yield of over $2200 \mathrm{~kg} \mathrm{ha}^{-1}$ compared with control ICCV 92944 $\left(1998 \mathrm{~kg} \mathrm{ha}^{-1}\right)$. All of them have the same crop duration (98 to $102 \mathrm{~d}$ ). Among the kabuli types, a large-seeded (40 g) 


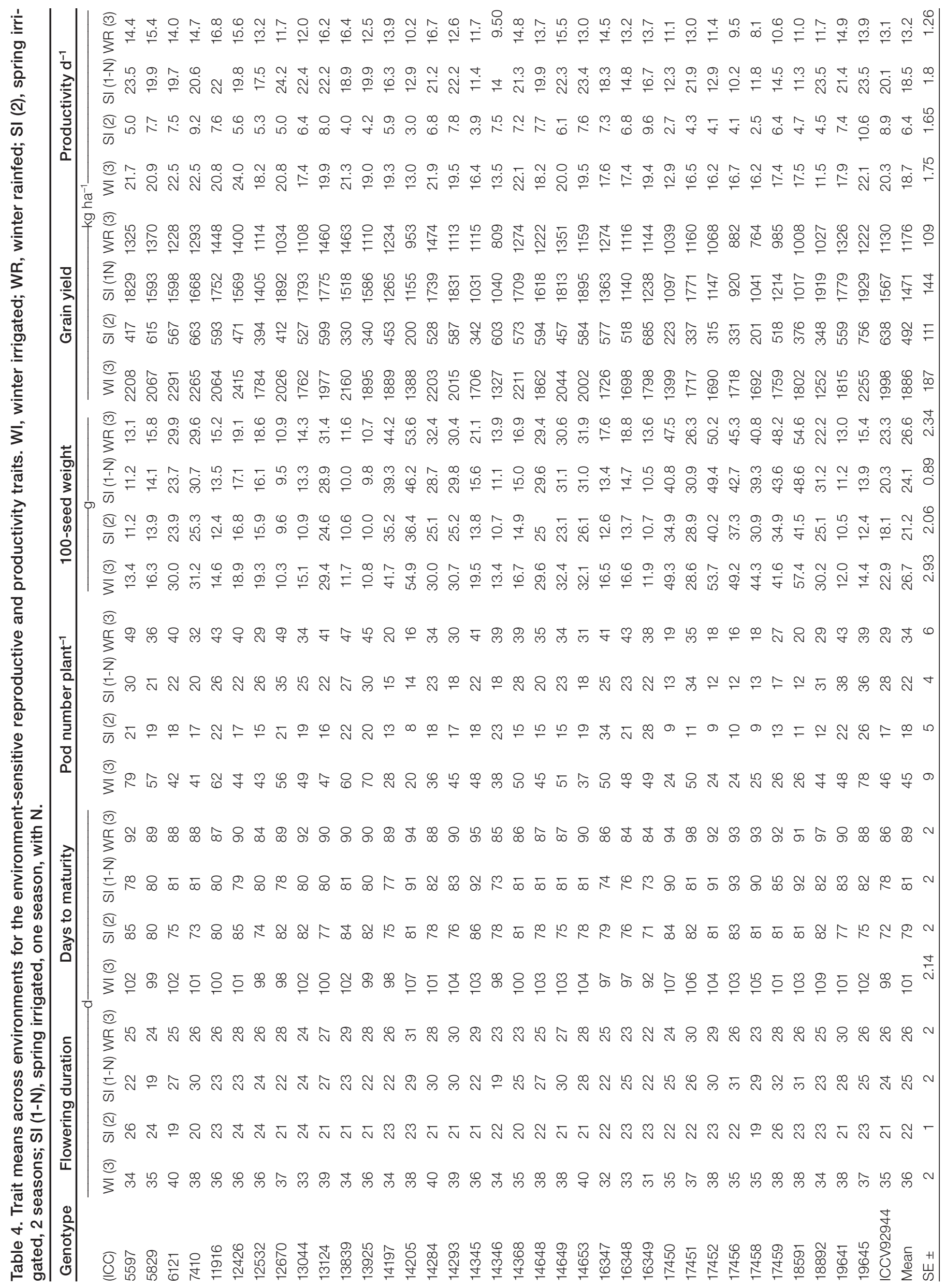


and early-maturing (98 d) accession, ICC $14197\left(1889 \mathrm{~kg} \mathrm{ha}^{-1}\right)$, was the nearest to the control. The genotype by environment interaction variance $\left(\sigma^{2}\right.$ ge) was highly significant only for DF, FD, DM, PH, PW, $\mathrm{APB}$, and SW, indicating that for these traits the genotypes interacted heavily with the environments.

\section{Spring Irrigated}

This crop was sown during the fourth week of January during 2007-2008 and 2008-2009 and during first week of February during 2009-2010. The spring irrigated (SI) crop period was characterized by rising temperature coupled with high intensity of solar radiation and longer day length. The $\sigma^{2} \mathrm{~g}$ was significant for all traits in all years except for tertiary branches (TB) in 2007-2008 and SP in 2009-2010, and in pooled analysis except for FD, $\mathrm{APB}$, and $\mathrm{TB}$. The $\sigma^{2}$ ge was significant for all traits except for BPB and basal secondary branches (BSB), indicating that for these two traits the genotypes do not interact with environments.

The crop performance diminished greatly under SI compared with WI in all aspects except DF. The trait means for SI indicate that the mean DF did not differ much from that of WI, but there was drastic reduction in FD and DM (Table 4). The overall mean FD was $36 \mathrm{~d}$ for WI, which decreased by $38.9 \%$ to $22 \mathrm{~d}$ for SI crops. The mean FD (year-wise) during 2009-2010 was just $18 \mathrm{~d}$ compared with $22 \mathrm{~d}$ and $28 \mathrm{~d}$ of $2008-$ 2009 and 2007-2008, respectively, with concurrent change in DM. The unusual rain of $173.0 \mathrm{~mm}$ after flowering during 2007-2008 may have induced extended flowering and maturity periods (Hall, 2004).

During 2007-2008 and 20092010 , the SI crop yields were low to the extent that the experimental mean yield of $565 \mathrm{~kg} \mathrm{ha}^{-1}$ (2007-2008) was only $33.4 \%$ of the WI crop, and the mean yield for
2009-2010 (408 $\left.\mathrm{kg} \mathrm{ha}^{-1}\right)$ was only $18.5 \%$ of WI. However, the experimental mean yield of $1460 \mathrm{~kg} \mathrm{ha}^{-1}$ during 2008-2009 was $85 \%$ of the WI crop of that year. This wide variation in mean yield between years is due to the application of an additional dose of $\mathrm{N}$ at $20 \mathrm{~kg} \mathrm{ha}^{-1}$ as urea at 25 DAS (at preflowering stage) during 2008-2009, which increased the pods plant ${ }^{-1}$ (PN) by 10 and $46.7 \%$ over the years 2007-2008 and 2009-2010, respectively. The mean 100-seed weight (SW; $14.9 \mathrm{~g}$ for 2008-2009) also increased by $0.6 \mathrm{~g}$ and $1.4 \mathrm{~g}$, respectively, over 2007-2008 and 20092010. This shows that $N$ could be a limiting factor for realizing better yield from the SI crop. The poor performance of all accessions during 2009-2010, in spite of five protective irrigations, may be the result of high temperatures $\left(>35^{\circ} \mathrm{C}\right.$, Tmax; $>25^{\circ} \mathrm{C}$, Tmin; and $>27^{\circ} \mathrm{C}$, Tmean) during the postflowering period. This high temperature coupled with high evapotranspiration may have imposed severe heat stress on the crop. Overall, none of the accessions were significantly superior to the control in any year. However, the two-year (2007-2008 and 2009-2010) mean yield indicated that ICC $19645\left(756 \mathrm{~kg} \mathrm{ha}^{-1}\right)$ and ICC 16349 (685 $\mathrm{kg} \mathrm{ha}^{-1}$ ) produced superior yield over the control. A kabuli accession ICC $17459\left(518 \mathrm{~kg} \mathrm{ha}^{-1}\right)$ produced consistently on-par yield with the control $\left(638 \mathrm{~kg} \mathrm{ha}^{-1}\right)$. During $2008-$ 2009 , though no genotype was significantly superior to the control (1567 kg ha $\left.{ }^{-1}\right)$, some-ICC $18892\left(1919 \mathrm{~kg} \mathrm{ha}^{-1}\right)$, ICC $14653\left(1895 \mathrm{~kg} \mathrm{ha}^{-1}\right)$, ICC 14293 (1831 kg ha-1) (all medium seeded), and ICC $12670\left(1892 \mathrm{~kg} \mathrm{ha}^{-1}\right)$ and ICC 5597 (1829 $\mathrm{kg} \mathrm{ha}^{-1}$ ) (both small seeded) - performed consistently better than the control $\left(1567 \mathrm{~kg} \mathrm{ha}^{-1}\right)$. ICC 14346 $\left(945 \mathrm{~kg} \mathrm{ha}^{-1}\right)$ was least sensitive to stress environments, with an STI (Stress Tolerance Index value, Fisher and Maurer, 1978; Ozkan et al., 1999) of 0.74, followed by ICC 16349 (0.84), while the control (ICCV 92944) showed an STI of 0.92 .

\section{Winter Rainfed}

The WR crop is a normal season crop that was grown under receding soil moisture conditions during the postrainy season. An occasional rain helped the crop (Fig. 1). The REML analysis indicated that $\sigma^{2} \mathrm{~g}$ was highly significant for DF, DM, PH, APB, ASB, PN, and SW in all years and inconsistent for other traits (year-wise data not given). The pooled $\sigma^{2} \mathrm{~g}$ was also significant for all traits except for the branching traits, APB, BSB, and TB and SP, and for YKGH and PROD. The $\sigma^{2}$ ge was significant only for DF, FD, DM, PH, APB, and SW for pooled data (Table 3).

The crop performance under WR was lower than WI but better than SI. The mean FD decreased by $26 \%$ to $26 \mathrm{~d}$, while the DM and PN decreased by 11 and 30\%, respectively (Table 4). The average yield ranged from 406 to $1304 \mathrm{~kg} \mathrm{ha}^{-1}$ in 2007-2008 with only one accession, ICC $12426(1304 \mathrm{~kg}$ $\left.\mathrm{ha}^{-1}\right)$, significantly superior over the control $\left(793 \mathrm{~kg} \mathrm{ha}^{-1}\right)$. The mean yields were high during 2008-2009 (1248 kg 
$\mathrm{ha}^{-1}$ ) and 2009-2010 (1372 $\left.\mathrm{kg} \mathrm{ha}^{-1}\right)$, but no accession was significantly superior to the control. The 2007-2008 crop was totally dependent on the receding residual soil moisture, whereas the 2008-2009 (26.6 $\mathrm{mm}$ at preflowering) and 2009-2010 (45 $\mathrm{mm}$ at preflowering and $46 \mathrm{~mm}$ at grain filling) crops received rain, which boosted the experimental mean yield by 30 and 39\%, respectively (Fig. 1). This indicated that sufficient soil moisture during reproductive and grain-filling periods is vital for high yield. The pooled analysis $(3 \mathrm{yr})$ for the WR crop revealed that four entries, ICC $14284\left(1474 \mathrm{~kg} \mathrm{ha}^{-1}\right)$ and ICC $13124\left(1460 \mathrm{~kg} \mathrm{ha}^{-1}\right)$, both medium seed type, and ICC $13839\left(1463 \mathrm{~kg} \mathrm{ha}^{-1}\right)$ and ICC 11916 (1448 $\mathrm{kg} \mathrm{ha}^{-1}$ ), both small seeded, were significantly better than the control cultivar $\left(1130 \mathrm{~kg} \mathrm{ha}^{-1}\right)$.

Overall, the WR crop produced about 32\% lower yield than the WI crop and 140\% more than the SI crop. However, when the SI crop was provided with additional nitrogen (Table 5), the WR crop yielded about 20\% less than the SI crop. The above results indicate that chickpea responds favorably to irrigation and nitrogen application and that off-season crops can be successfully raised with better crop management.

\section{Pooled Analysis}

The pooled analysis was done over six (three WI and three SI) and nine (three WR, three WI, and three SI) environment groups, apart from three environments (seasons) under each regime. This was done considering the two irrigated regimes together as a second group and all three regimes together as the third. The REML analysis (Table 3) indicated that both $\sigma^{2} \mathrm{~g}$ and $\sigma^{2}$ ge were highly significant for reproductive traits DF, FD, and DM and for PH, in all environments and for all three types of pooled analyses, except $\sigma^{2} \mathrm{~g}$ for FD in three SI and six (three WI + three SI) pooled analyses. This indicated that genotypic differences were highly significant and consistent across seasons for these traits in spite of their being highly interactive with environments. The $\sigma^{2}$ g and $\sigma^{2}$ ge, though statistically significant, were not consistent for PW and branching traits, and even their magnitude was very low, indicating that the genotypic differences for these traits were small and inconsistent across seasons. Among the branching traits, APB appeared to be relatively more important than others. Both $\sigma^{2} \mathrm{~g}$ and $\sigma^{2}$ ge were highly significant for all pooled analyses for PN and SW, except for PN in three WI and three WR pooled analyses. The $\sigma^{2} \mathrm{~g}$ for YKGH and PROD was highly significant for only two environments (WI and SI) and pooled analyses and not for WR, while $\sigma^{2}$ ge was significant only for SI and for pooled analyses. This indicates that the traits PN, SW, YKGH, and PROD are highly interactive with extreme environments (WI, the ideal, and SI, the heat stress). The magnitude of both $\sigma^{2} \mathrm{~g}$ and $\sigma^{2}$ ge for $\mathrm{SP}$ was minimal in all seasons, indicating the low genotype differences for this trait. The ratio between $\sigma^{2} \mathrm{~g}$ and $\sigma^{2} \mathrm{ge}$ (for nine environments) was less than 1 for PW, APB, and $\mathrm{TB}$, indicating that their seasonal variability was largely due to interaction effects of genotypes and environments rather than heritable genetic differences.

The genotypic responses were variable across environments. The $3 \mathrm{yr}$ pooled analysis revealed a common trend, namely, the yield of the spring-irrigated, two seasons (SI [2]), without nitrogen crop was just $26 \%$ of the WI and $42 \%$ of the WR crops (Table 5 ). The major cause of this low yield is the reduction in PN and SW due to heat stress as adequate irrigation was provided to avoid moisture stress. There was no appreciable reduction in seed number per pod. The mean PN was 45 for WI, 34 for WR, and 18 for SI (2). The SW also reduced by $21 \%$ in SI (2) against WI or WR. The main cause for reduction in PN may be that the FD was $36 \mathrm{~d}$ for WI, $26 \mathrm{~d}$ for WR, and $22 \mathrm{~d}$ for SI (2). This reduced FD, coupled with postflowering heat stress, may have resulted in flower drop and abortion of young pods (Warrag and Hall, 1983). The mean yield of spring irrigated, one season (SI [1]), with additional nitrogen was $1471 \mathrm{~kg} \mathrm{ha}^{-1}$ (78.5\% of WI and $125 \%$ of WR). Comparison of the three-year results of SI clearly shows that application of additional $\mathrm{N}$ resulted in $>100 \%$ increase in yield over nonapplication, and the yield was comparable to WI (80\%) or WR (125\%) crops.

The experimental means for different characters varied widely between planting regimes and moderately between years (Table 4). The SI-planted crop recorded the lowest values for all traits except DF, for which the variability is low, which indicates that during all years and all planting regimes the DF occurred within about a week's time (33 to $42 \mathrm{~d}$ ) in all genotypes and environments. Productivity, PN, FD, DM, and vegetative traits showed more variability between planting regimes and low to moderate variability between years. The SW varied moderately, while the SP was nearly uniform in all environments.

Overall pooled analysis (nine environments) revealed that no accession was significantly superior to the control, ICCV 92944, for grain yield (Table 5). However, two accessions, ICC 7410 and ICC 19645, were consistently superior to the control in all environments, but their response to irrigation and additional nitrogen was average. ICC 5597, ICC 5829, ICC 6121, ICC 13124, ICC 14284, ICC 14649, ICC 14653, ICC 12426, ICC 14368, and ICC 11916 produced consistently higher yield than the control to the extent of 15 to $20 \%$ in different environments except SI (2). In the SI (2) environment, ICC 7410, ICC 16349, and 19645 were superior to the control. The kabuli type, ICC 14197, was at par with the control. It has the same DM but large SW (40 g) compared with the control $(20 \mathrm{~g})$ and may be preferred by consumers. Thus, ICC 12426, ICC 14368, and ICC 11916 (desi type) and ICC 14197 (kabuli type), are found to be promising for heat-stress situations under an irrigated ecosystem. 


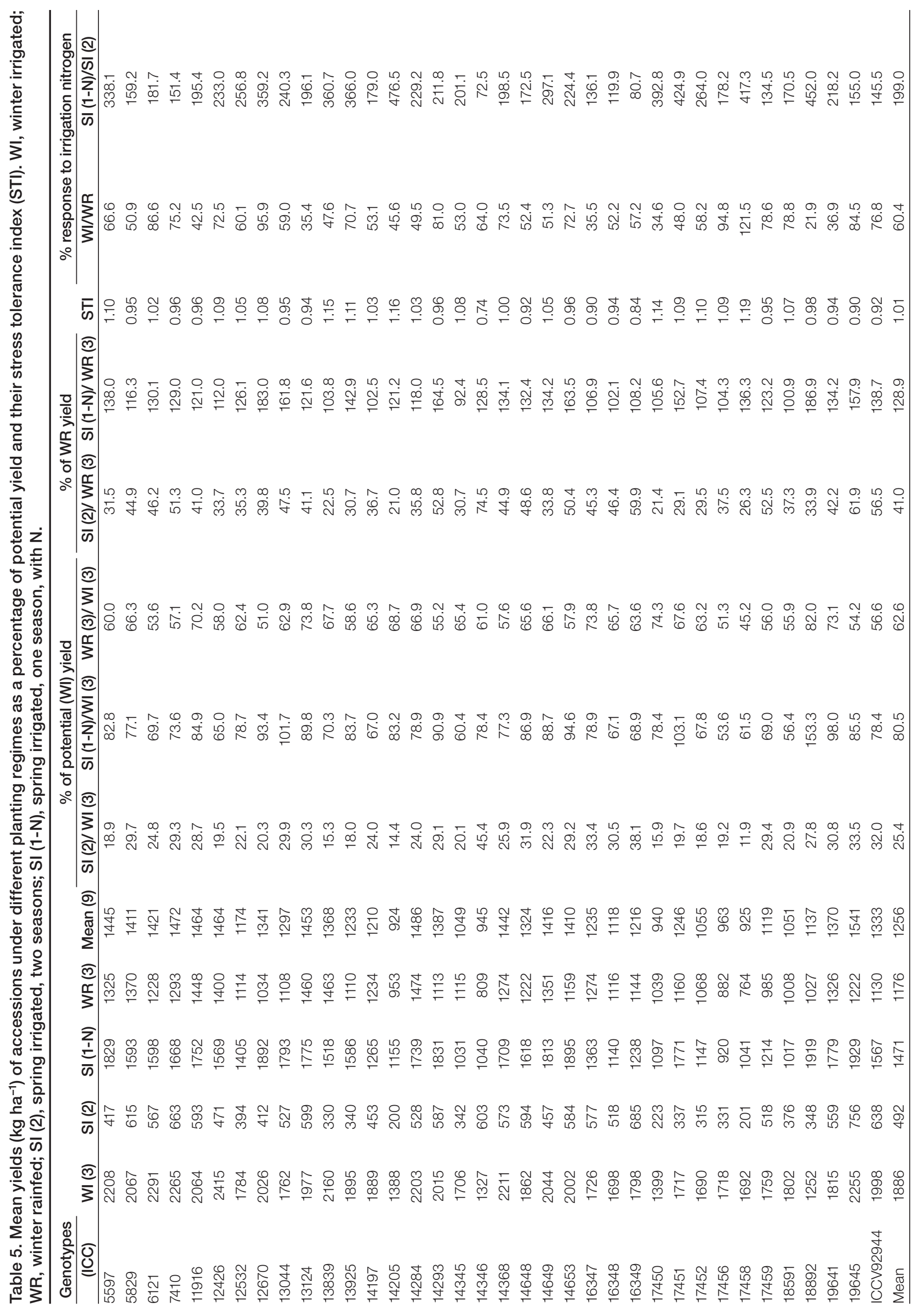


Considering the average yield of each accession under the WI situation as its potential yield, their respective mean yield under WR and SI situations was reduced significantly. On average the SI (2) crop produced only $26 \%\left(492 \mathrm{~kg} \mathrm{ha}^{-1}\right)$ of the WI crop (1886 kg ha-1), the genotypic means varying from 11.9 to $45.4 \%$. while the WR crop produced $\sim 62 \%$ $\left(1176 \mathrm{~kg} \mathrm{ha}^{-1}\right)$ of the WI crop, the individual accessions ranging from 45.2 to $82.0 \%$ of their respective yield under WI. When SI and WR are considered together, the SI (2) crop produced $42 \%$ of the WR crop; the genotypic means ranged from 21.0 to $74.5 \%$ of their respective yield under the WR regime. The SI (1) crop was $78 \%$ of the WI, the genotypes varying from 53.6 to $153.3 \%$, but equal or greater ( 92.4 to $186.9 \%)$ than the WR crop. Conversely, considering the WR crop as the standard, the WI crop produced, on average, 60\% more yield than WR, the genotypic response ranging from 21.9 (ICC 18892) to $121.5 \%$ (ICC 17458) over their respective WR yield. Gaur et al. (2007) reported an average reduction of $\sim 5 \%$ or less for $\mathrm{DF}$ and $\mathrm{PH}$ but higher reduction for SW (13\%), DM (21\%), PN (43\%), and yield per plant (51\%) from winter crop (October-January) to spring crop (January-April) among desi types and 18 to 30\% reduction in kabuli types. In our results the kabuli types were more sensitive than desi types. The average response to additional nitrogen was $200 \%$ over normal crop for SI (1), the genotypic response ranging from 172.5 (ICC 14346) to $476.5 \%$ (ICC 14205) over their respective normal SI (2) yield.

The significant reduction due to heat stress in plant height, width, and branching (and the resultant canopy size) as well as yield components PN, SW, YKGH, and PROD from WI to WR and SI is similar among all the accessions, which is very clear from the data. The reaction of the genotypes to heat stress was parallel and highly significant without any crossover type of genotype $x$ environment interaction. The response to favorable environment (WI) is also linear for all genotypes. Next to yield, PN and SW among yield traits and FD and DM among reproductive traits suffered most under heat stress. Among the vegetative traits, plant volume (PH and $\mathrm{PW}), \mathrm{APB}$, and $\mathrm{ASB}$ were severely stressed (Table 6). The reason may be that the heat stress actually began from flowering onward with increasing diurnal temperature and accompanying changes in other weather factors. Heat stress normally decreases the duration of developmental phases, leading to smaller organs, reduced light perception, and carbon assimilation processes including transpiration, photosynthesis, and respiration (Stone, 2001). The rising atmospheric $\mathrm{CO}_{2}$ content will drive temperature increases in many already stressful environments (Wahid et al., 2007), and the heat stress injures the photosynthetic apparatus, resulting in reduced plant volume during vegetative growth and diminished source activity and sink capacity during reproductive growth (Harding et al., 1990). A threshold temperature of $46^{\circ} \mathrm{C}$, beyond which photosynthesis may completely stop because of irreversible
Table 6. Range of variability of various traits across different planting environments in early-maturing chickpea (Cicer arietinum L.) germplasm accessions at ICRISAT, Patancheru, India, 2007-2008 to 2009-2010.

\begin{tabular}{|c|c|c|c|c|}
\hline Trait & $\begin{array}{c}\text { Winter } \\
\text { irrigated }\end{array}$ & $\begin{array}{l}\text { Spring } \\
\text { irrigated }\end{array}$ & $\begin{array}{l}\text { Spring } \\
\text { irrigated } \\
\text { with } \\
\text { nitrogen }\end{array}$ & $\begin{array}{l}\text { Winter } \\
\text { rainfed }\end{array}$ \\
\hline$\overline{\text { Days to flowering (no.) }}$ & $28-47$ & $27-44$ & $28-41$ & $27-45$ \\
\hline Flowering duration (d) & $31-40$ & $16-22$ & $19-31$ & $22-31$ \\
\hline Maturity (d) & 83-109 & $67-86$ & $72-93$ & $75-98$ \\
\hline Plant height (cm) & 29-72 & $19-54$ & $26-59$ & $27-51$ \\
\hline Plant width (cm) & $33-44$ & $21-28$ & $18-36$ & $28-31$ \\
\hline Basal primary branches (no.) & $1.8-2.9$ & $1.6-2.4$ & $0.6-2.1$ & $1.6-3.0$ \\
\hline Apical primary branches (no.) & $2.6-3.4$ & $1.1-2.6$ & $2.1-4.0$ & $1.8-3.9$ \\
\hline Basal secondary branches (no.) & $0.4-2.7$ & $0.2-2.7$ & $0.1-1.3$ & $0.5-2.0$ \\
\hline Apical secondary branches (no.) & $2.0-6.4$ & $1.1-4.7$ & $0.7-5.0$ & $1.1-5.7$ \\
\hline Tertiary branches (no.) & $0.2-1.3$ & $0.2-1.7$ & $0.0-0.4$ & $0.1-0.6$ \\
\hline Pods plant ${ }^{-1}$ (no.) & $20-78$ & $8.0-34.0$ & $12.0-54.0$ & $16.0-49$. \\
\hline Seeds pod ${ }^{-1}$ (no.) & $1.0-1.5$ & $1.2-1.4$ & $1.4-1.6$ & $1.0-1.6$ \\
\hline Seed weight $\left(100 \mathrm{~g}^{-1}\right)$ & $10.3-57.4$ & $9.6-48.9$ & $9.5-49.4$ & $10.7-54.6$ \\
\hline Yield $\left(\mathrm{kg} \mathrm{ha}^{-1}\right)$ & $1197-2415$ & $201-756$ & 645-1919 & $764-1474$ \\
\hline Productivity $\left(\mathrm{kg} \mathrm{ha}^{-1} \mathrm{~d}^{-1}\right)$ & $11.5-24.0$ & $2.5-10.6$ & $10.0-23.5$ & $8.1-16.8$ \\
\hline
\end{tabular}

damage to the photosynthetic system, and quantum decline in yield was reported for chickpea (Basu et al., 2009).

Interaction between photoperiod and temperature can influence the rate of floral bud development in certain genotypes, and in these cases, floral bud development is slowed down or completely suppressed in hot long-day conditions (Ehlers and Hall, 1996). Heat-stress-induced sterility may also be a cause for a drastic reduction in pod number when heat is imposed immediately before or during anthesis. Pulse legumes are particularly sensitive to heat stress at the bloom stage; only a few days of exposure to high temperatures $\left(30-35^{\circ} \mathrm{C}\right)$ can cause heavy flower drop or pod abortion (Siddique et al., 1999). Pollen viability and germination were reduced when temperature reached $35^{\circ} \mathrm{C}$, but these varied widely across genotypes (Basu et al., 2009). The pod set can be reduced to zero by a high night temperature $\left(30^{\circ} \mathrm{C}\right)$ or a combination of moderately hot nights $\left(27^{\circ} \mathrm{C}\right)$ and very hot days $\left(36^{\circ} \mathrm{C}\right)$ (Warrag and Hall, 1983). When the minimum temperature increased from 15 to $27^{\circ} \mathrm{C}$, a $50 \%$ reduction in pod set was observed in cowpea (Vigna unguiculata L. Walp.), suggesting that heat stress may be the cause for substantial reduction in grain yield in the warmer environments (Nielsen and Hall, 1985a). From growth chamber and greenhouse studies in tomato (Lycopersicon esculentum Mill.), Foolad (2005) reported that high temperature was most deleterious when flowers were first visible, and sensitivity continued for 10 to $15 \mathrm{~d}$. In tomato, though plants are sensitive to high temperatures throughout the plant ontogeny, flowering and fruit set are the most sensitive stages; fruit set is moderately affected at day/night temperatures above $26 / 20^{\circ} \mathrm{C}$ and is severely affected above $35 / 26^{\circ} \mathrm{C}$ (Berry and Rafique-Uddin, 1988). Poor fruit set in tomato at high temperature was associated with low levels of carbohydrates and 
growth regulators released in plant sink tissues (Kinet and Peet, 1997). In wheat (Triticum aestivum L.), both grain weight and grain number were found to be sensitive to heat stress, as the number of grains per ear at maturity declined with increasing temperature (Ferris et al., 1998).

For achieving high grain yields the cultivars should have an optimum reproductive period, which is influenced by temperature. Hall (2004) reported reduction in the period from first flowering to physiological maturity with hotter temperatures to the extent of $19 \mathrm{~d}$ (from 50 to $31 \mathrm{~d}$ ) in cowpea grown in subtropical and tropical environments. The rate of pod development is strongly influenced by night temperature. In cowpea, the period from anthesis to maturity of individual pods decreased linearly from 21 to $14 \mathrm{~d}$ with an increase in minimal night temperature from 15.5 to $26.6^{\circ} \mathrm{C}$, which is typical of hot tropics (Nielsen and Hall, 1985b). Genotypic variation for the pod development period in cowpea is positively associated with individual seed weight. For very small seeds $\left(50 \mathrm{mg} \mathrm{seed}^{-1}\right)$, the pod development period was $17 \mathrm{~d}$, whereas with moderately large seeds $\left(200 \mathrm{mg} \mathrm{seed}^{-}\right.$ $\left.{ }^{1}\right)$, it was $21 \mathrm{~d}$ (Wien and Ackah, 1978). The hastened maturity (early maturity) may be due to faster senescence induced by the weakened photosynthetic apparatus. Brief exposure of plants to high temperatures during seed filling can accelerate senescence, diminish seed set and seed weight, and reduce yield (Siddique et al., 1999). This is because under such conditions plants tend to divert resources to cope with heat stress, and, thus, limited photosynthates would be available for reproductive development. Reduction in kernel growth due to heat stress was observed in spring wheat, leading to losses in kernel density and weight up to 7\% (Guilioni et al., 2003) and reduced grain weight and grain number (Ferris et al., 1998), as the number of grains per ear at maturity declined with increasing temperature.

Basu et al. (2009) reported that out of a large number of chickpea genotypes evaluated, more than $90 \%$ failed to set pods when temperature suddenly increased to $41^{\circ} \mathrm{C}$ under spring conditions. However, ICCV 92944 (control) and a few others could set pods with normal seeds, while a majority produced shriveled or deformed grains with reduced size. The critical temperature range for damage to reproductive organs was found to be between 35 and $40^{\circ} \mathrm{C}$, and sensitivity varied among genotypes. They identified ICCV 92944 as a putatively heat-tolerant line.

\section{Heritability}

The heritability in broad sense $\left(h^{2} b\right)$ estimate is a reflection of the range of variability for a quantitative trait among a group of genotypes, such that if variability is low, the estimate of $h^{2} b$ would be minimal. Our results indicate that the characters DF, DM, PH, BPB, BSB, ASB, PN, SW, YKGH, and PROD with high $h^{2} b(>60 \%)$, which effectively highlighted the difference between accessions, can be used as a primary set of criteria for selection in both favorable and stressful environments.

\section{Relationship between Climate Factors and Plant Traits}

Among the correlations between climate factors and plant traits, the preflowering rainfall showed a moderate $(0.55$ to 0.63 ) but significant positive correlation with FD, DM, and $\mathrm{PW}$ and a low (0.28 to 0.39) positive correlation with $\mathrm{PH}$, $\mathrm{BPB}, \mathrm{APB}, \mathrm{ASB}$, and $\mathrm{PN}$, while postflowering rainfall showed a low positive correlation with APB (0.34) and SP (0.28). The DL showed a weak (0.22) positive correlation with only DF (data not given). This may be because the mean or range of genotypes for DF did not vary between winter and spring seasons, while individual genotypes varied from -4 to $5 \mathrm{~d}$. The RH had high positive correlations with FD (0.73), DM (0.80), and PW (0.83) and moderate positive correlations with other traits (Table 7). The Tmean showed a very high $(>0.90)$ positive relationship with DL, PE, and ISR, and because of this, these weather components influenced the plant traits in an identical manner. All these had shown a very high significant negative correlation with FD, DM, and PW (-0.81 to $-0.89)$ and YKGH $(-0.73$ to -0.80$)$ and moderate but highly significant negative correlations with PROD $(-0.60$ to -0.67$)$, $\mathrm{PN}(-0.56$ to -0.71$), \mathrm{BPB}, \mathrm{APB}$, and $\mathrm{PH}(-0.32$ to -0.51$)$. The WV had high negative correlation $(>-0.72)$ with DM, YKGH, and PROD and moderate negative correlation with PH, PW, BPB, ASB, and PN (-0.27 to -0.57$)$. The DBS had only moderate negative correlation $(<-0.57)$ with FD, DM, PW, BPB, APB, ASB, and PN. The SW was not correlated with any weather factor (Table 7).

\section{Relationship between Plant Traits}

The correlations between plant traits on the basis of environmental mean data (data not given) were highly significant, and meaningful correlations (where $r=>0.71$ and $R^{2}=>0.50$ ) were considered along with some important moderate $(0.28$ to 0.70$)$ correlations of yield components. The primary yield components $\mathrm{PN}$ and SW showed a strong negative correlation $(-0.90)$ with each other. The PN had a high positive correlation with all branching traits, SP, YKGH, and PROD (0.66 to $0.82)$, while SW had a high negative correlation $(>-0.70)$ with $\mathrm{APB}, \mathrm{PN}$, and SP and moderate $(-0.43$ to -0.63$)$ negative correlation with $\mathrm{DF}, \mathrm{BPB}, \mathrm{BSB}, \mathrm{ASB}$, and TB but positive correlation with FD, DM, and PH. Grain yield and PROD showed a strong $(>0.70)$ positive association with $\mathrm{BPB}$ and ASB and negative association with $\mathrm{PH}$ and a moderate negative correlation with DM, PW, TB, and SW. The branching traits were strongly and positively correlated with each other. Increasing the PN by improving the branching traits and simultaneously weakening the strong negative correlation between $\mathrm{PN}$ and SW can increase the yield potential of these early maturing genotypes in any environment.

\section{Multiple Regression Analysis}

Estimation of the effect of each climatic variable on all 15 criterion plant traits was done through regression analysis 
Table 7. Correlations between climate factors and plant traits of early-maturing chickpea (Cicer arietinum L.) germplasm at ICRISAT, Patancheru, India.

\begin{tabular}{|c|c|c|c|c|c|c|c|}
\hline Variable & $\begin{array}{l}\text { Mean } \\
\text { temp. }\end{array}$ & $\begin{array}{l}\text { Day } \\
\text { length }\end{array}$ & Evaporation & $\begin{array}{c}\text { Solar } \\
\text { radiation }\end{array}$ & $\begin{array}{l}\text { Relative } \\
\text { humidity }\end{array}$ & $\begin{array}{c}\text { Wind } \\
\text { velocity }\end{array}$ & $\begin{array}{c}\text { Bright } \\
\text { sunshine }\end{array}$ \\
\hline & ${ }^{\circ} \mathrm{C}$ & $\mathrm{h}$ & $\mathrm{mm}$ & $\mathrm{Mj} / \mathrm{m}^{2}$ & $\%$ & $\mathrm{~km} \mathrm{~h}-1^{-1}$ & $\mathrm{~h}$ \\
\hline Mean temperature $\left({ }^{\circ} \mathrm{C}\right)$ & 1.00 & 0.96 & 0.98 & 0.94 & -0.88 & 0.75 & 0.40 \\
\hline Day length (h) & & 1.00 & 0.97 & 0.95 & -0.82 & 0.86 & 0.36 \\
\hline Evaporation (mm) & & & 1.00 & 0.98 & -0.93 & 0.74 & 0.52 \\
\hline Solar radiation $\left(\mathrm{Mj} / \mathrm{m}^{2}\right)$ & & & & 1.00 & -0.94 & 0.69 & 0.62 \\
\hline Relative humidity (\%) & & & & & 1.00 & -0.45 & -0.78 \\
\hline Wind velocity $\left(\mathrm{km} \mathrm{h}^{-1}\right)$ & & & & & & 1.00 & -0.10 \\
\hline Flowering duration (d) & -0.88 & -0.84 & -0.83 & -0.81 & 0.73 & -0.67 & -0.28 \\
\hline Maturity (d) & -0.89 & -0.89 & -0.88 & -0.88 & 0.80 & -0.72 & -0.38 \\
\hline Plant height (cm) & -0.44 & -0.35 & -0.36 & -0.27 & 0.28 & -0.33 & $<0.1$ \\
\hline Plant width $(\mathrm{cm})$ & -0.85 & -0.81 & -0.86 & -0.87 & 0.83 & -0.57 & -0.54 \\
\hline Basal primary branches (no.) & -0.39 & -0.48 & -0.47 & -0.57 & 0.50 & -0.27 & -0.55 \\
\hline Apical primary branches (no.) & -0.32 & -0.25 & -0.34 & -0.37 & 0.38 & $<0.1$ & -0.39 \\
\hline Apical secondary branches (no.) & -0.40 & -0.45 & -0.43 & -0.51 & 0.43 & -0.27 & -0.42 \\
\hline Pods plant ${ }^{-1}$ (no.) & -0.56 & -0.62 & -0.63 & -0.71 & 0.62 & -0.42 & -0.57 \\
\hline Yield (kg ha $\left.{ }^{-1}\right)$ & -0.73 & -0.80 & -0.73 & -0.75 & 0.53 & -0.79 & $<0.1$ \\
\hline Productivity (kg ha ${ }^{-1} \mathrm{~d}^{-1}$ ) & -0.60 & -0.67 & -0.60 & -0.61 & 0.37 & -0.74 & $<0.1$ \\
\hline
\end{tabular}

using all 10 climatic variables. Of the different models evaluated, multiple regression equations, developed using only six predictors (climate factors-Tmean, DL, DBS, ISR, $\mathrm{RH}, \mathrm{WV}$, and PE) to estimate the expected mean value of each trait for a given environment, showed an excellent agreement (with a negligible $\chi^{2}$ value) between the predicted and the actual (data not given). The adjusted $R^{2}$ values were very high $(>0.85)$ for FD, YKGH, and PROD, indicating that the expression of these traits can be predicted correctly on the basis of these environmental predictors. For predicting PW, WV was replaced by DBS. However, the DM required an additional predictor, $\mathrm{BSH}$, for achieving a high adjusted $R^{2}$ value of 0.86 . The $R^{2}$ values for SP and SW were very low $(<0.10)$, indicating that perhaps these two traits are not so vulnerable to the environment. The DL, ISR, RH, and WV affected most traits, while the Tmean mainly influenced the reproductive and yield traits. The DF, FD, DM, and YKGH were under the influence of all climatic factors except DBS. The partitioning of incidental climatic factors into preflowering and postflowering subgroups showed a similar trend, except for Tmin. The Tmin of the postflowering period showed strong negative correlations with reproductive and yield traits, while preflowering Tmin showed weak correlations with all traits. This may be due to enhanced respiration during the night because of high night temperature.

\section{Mitigation of Heat Stress}

Under the SI regime during 2008-2009, an additional dose of $\mathrm{N}$ at $20 \mathrm{~kg} \mathrm{ha}^{-1}$ in the form of urea was applied at the preflowering stage as the crop canopy appeared to be pale green. This additional $\mathrm{N}$ benefited the crop enormously, as can be seen from the comparative data (Table 5 and Fig. 2). All the accessions responded to $\mathrm{N}$ and produced near normal yield ( $80 \%$ of WI and $28 \%$ more than WR), and the crop actually flowered early, had longer FD and DM, higher PN, and high SW (data not given). The response of chickpea to additional N was observed by Bahr (2007) under Egyptian climate. He reported that foliar application of urea $(1 \%)$ at pod filling resulted in taller plants with increased branching, pod and seed number per plant, seed weight, grain yield, and harvest index in the normal winter crop. Our study also indicates differential response of genotypes to additional N. ICC 14205, ICC 18892, ICC 17451, ICC 17458, and ICC 17450 have shown $>400 \%$ response to $\mathrm{N}$ compared with SI (2) means. During spring, with additional N and protective irrigation, ICC 19641, ICC 13044, and ICC 17451 produced seed yield similar to their WI yield. Thus it appears that additional $\mathrm{N}$ can improve the heat tolerance of the spring chickpea and help produce near normal yield irrespective of the genotype as shown by our data. The inability of both the crop as well as the symbiotic Rhizobia to support each other under high-temperature conditions may be the probable reason for the high response to added $\mathrm{N}$. The effect of other nutrients also deserves attention to completely mitigate the effect of heat stress. The response of the winter crop to irrigation was similar but of lesser degree. The genotypes ICC 17458, ICC 6121, ICC 12670, ICC 19645 , and ICC 17456 showed $>80 \%$ response to irrigation. The genotype ICC 17458 gave the highest response to both irrigation and $\mathrm{N}$ application.

Overall, 10 accessions, ICC 5597, ICC 5829, ICC 6121, ICC 7410, ICC 11916, ICC 13124, ICC 14284, ICC 14346, ICC 14368 , and ICC 14653, all desi types, were identified as heat-stress tolerant. These accessions can be used in chickpea improvement programs for developing heat-tolerant cultivars and for inheritance studies. These accessions originated from India (seven accessions), Iran (two accessions), and Russia and 


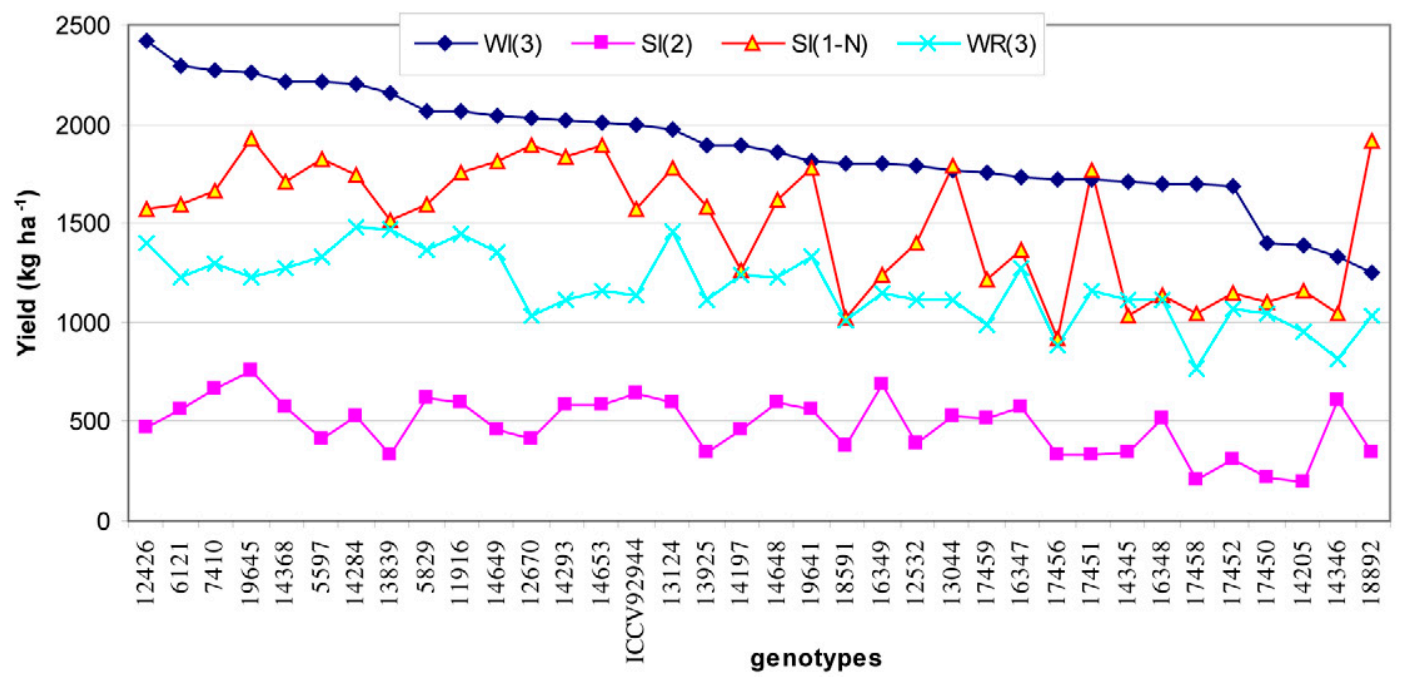

Figure 2. Mean response of genotypes to winter-irrigated (WI), spring-irrigated (SI [2]), spring-irrigated with N (SI [1-N]), and winter-rainfed (WR) environments; figures in parentheses indicate number of seasons.

Commonwealth of Independent States (one accession) (Table 1). The georeference data of only two accessions, ICC 14284 and ICC 14653 (both landraces), are available. ICC 14284 was collected from Udumalpet, Coimbatore, Tamil Nadu (latitude $10^{\circ} \mathrm{N} 58^{\prime}$, longitude $77^{\circ} \mathrm{E} 24^{\prime}$, altitude 400 m.a.s.1.), and ICC 14653 was collected from Ujjain, Madhya Pradesh, India $\left(23^{\circ} 05^{\prime} \mathrm{N}, 75^{\circ} 38^{\prime} \mathrm{E}, 555\right.$ m.a.s.1.). These two locations are at extreme ends of the "Deccan Plateau," with a characteristic climate of the semiarid tropics. Our database indicated the presence of 99 additional accessions within a $75-\mathrm{km}$ radius of these two collecting sites. However, these are later maturing than the 35 accessions used in the present study. In future, collection missions to these areas should focus on collecting the early-maturing types.

Four other significant findings that can be inferred from this study are:

1. Chickpea responds to irrigation, and genotypes respond linearly but differentially to irrigation: ICC 12670 and ICC 17458 have produced $\sim 100 \%$ more yield under WI compared to WR, the response varying from $22 \%$ (ICC 18892) to 122\% (ICC 17458).

2. Heat stress reduces the potential grain yield up to a maximum of $85 \%$ (ICC 13839 and ICC 14205), and sensitivity varied across genotypes.

3. Application of additional $\mathrm{N}$ fertilizer at the preflowering stage can mitigate the heat stress to a large extent where the yield reduction could be limited to $20 \%$ (mean of all accessions) in the SI compared with the WI crop. The yield response to additional $\mathrm{N}$ of the SI crop (2008-2009) was very high ( 200\%) compared with SI of 2007-2008 or 2009-2010 (with no N) for all genotypes, and genotypes responded differentially. However, these findings need to be confirmed.

4. The heat stress accelerates the plant growth phases, as evident from the reduced reproductive and maturity duration as the plant races to complete its life cycle before the onset of extreme stress.

Plants under high-stress conditions exhibit a variety of symptomatic responses and quantitative changes in their growth and morphology. The plant's ability to cope with or adjust to the stress varies across and within species as well as at different developmental stages, the later phenological stages being more susceptible (Wahid et al., 2007). Therefore, assessment of tolerance and identification, characterization, and genetic manipulation of tolerance components at all stages of the plant life cycle is necessary. Recent genetic studies and efforts to understand and improve the high-temperature tolerance of crop plant traits have mostly determined that it is a multigenic trait. Different components of tolerance, controlled by different sets of genes, are critical for heat tolerance at different stages of plant development or in different tissues (Howarth, 2005). Siddique et al. (1999) suggested that future breeding programs should emphasize (i) design and development of accurate screening procedures, (ii) identification and characterization of genetic resources with heat tolerance, (iii) discerning the genetic basis of heat tolerance at each stage of plant development, and (iv) development and screening of large breeding populations to facilitate transfer of genes for heat tolerance to adapted cultivars.

\section{CONCLUSIONS}

Our study revealed that variation in climatic factors, such as Tmean, DL, DBS, ISR, RH, WV, and PE, induce severe heat stress in the spring-grown chickpea. Overall, the heat stress reduced the canopy size and affected different plant traits in different genotypes to an extent of 21 to $74 \%$. Yield loss among genotypes varied from 10 to $15 \%$ for every degree increase in temperature beyond optimum. Heat stress can be mitigated by the application of $20 \mathrm{~kg} \mathrm{~N} \mathrm{ha}^{-1}$ and irrigation to a large extent. We 
identified several germplasm lines that are heat tolerant and responsive to stress mitigation management for use in breeding programs. We suggest an extensive evaluation of the chickpea germplasm mini core collection (10\% of core or $1 \%$ of entire collection) for heat tolerance and response to nutrient and irrigation management to identify the best germplasm lines for effective crop improvement. Combined together, the in-built tolerance to heat stress and response to management will help overcome the adverse effects of climate change on chickpea.

\section{References}

Bahr, A.A. 2007. Effect of plant density and urea foliar application on yield and yield components of chickpea (Cicer arietinum). Res. J. Agric. Biol. Sci. 3:220-223.

Basu, P.S., A. Masood, and S.K. Chaturvedi. 2009. Terminal heat stress adversely affects chickpea productivity in northern India-Strategies to improve thermo tolerance in the crop under climate change. p. 189-193. In Proceedings of the XXXVIII Workshop of the International Society for Photogrammetry and Remote Sensing: Impact of Climate Change on Agriculture. ISRO, Ahmedabad, India.

Berry, S.Z., and M. Rafique-Uddin. 1988. Effect of high temperature on fruit set in tomato cultivars and selected germplasm. HortScience 23:606-608.

DerSimonian, R., and N. Laird. 1986. Meta-analysis in clinical trials. Control. Clin. Trials 7:177-188. doi:10.1016/01972456(86)90046-2

Easterling, W., P. Aggarwal, P. Batima, K. Brander, L. Erda, M. Howden, A. Kirilenko, J. Morton, J.-F. Soussana, J. Schmidhuber, and F. Tubiello. 2007. Food, fibre and forest products. p. 273-313. In M.L. Parry, O.F. Canziani, J.P. Palutikof, P.J. van der Linden, and C.E. Hanson (ed.) Climate change 2007: Impacts, adaptation and vulnerability. Cambridge Univ. Press, Cambridge, UK.

Ehlers, J.D., and A.E. Hall. 1996. Genotypic classification of cowpea based on responses to heat and photoperiod. Crop Sci. 36:673679. doi:10.2135/cropsci1996.0011183X003600030026x

FAO. 2008. http://faostat.fao.org/site/567/desktopdefault.aspx?pageid $=567 \#$ ancor.

Ferris, J. 1999. An analysis of the impact of ENSO (El Niño/Southern Oscillation) on global crop yields. Am. J. Agric. Econ. 81:1309.

Ferris, R., R.H. Ellis, T.R. Wheeler, and P. Hadley. 1998. Effect of high temperature stress at anthesis on grain yield and biomass of field grown crops of wheat. Plant Cell Environ. 34:67-78.

Fisher, R.A., and R. Maurer. 1978. Drought resistance in spring wheat cultivars. I. Grain yield response. Aust. J. Agric. Res. 29:897-912. doi:10.1071/AR9780897

Foolad, M.R. 2005. Breeding for abiotic stress tolerances in tomato. p. 613-684. In M. Ashraf and P.J.C. Harris (ed.) Abiotic stresses: Plant resistance through breeding and molecular approaches. The Haworth Press, New York.

Gaur, P.M., C.L.L. Gowda, and B.V. Rao. 2007. Rapid generation advancement in chickpea [Online]. Available at ejournal. icrisat.org. SAT eJournal. Vol. 3 (1).

Gowda, C.L.L., H.D. Upadhyaya, N. Dronavalli, and S. Singh. 2011. Identification of large-seeded high-yielding stable kabuli chickpea germplasm lines for use in crop improvement. Crop Sci. 51:198-209. doi:10.2135/cropsci2010.01.0078

Guilioni, L., J. W'ery, and J. Lecoeur. 2003. High temperature and water deficit may reduce seed number in field pea purely by decreasing plant growth rate. Funct. Plant Biol. 30:1151-1164. doi:10.1071/FP03105

Hall, A.E. 2004. Comparative ecophysiology of cowpea, common bean and peanut. p. 271-324. In Nguyen, H.T., and A. Blum (ed.) Physiology and biotechnology integration for plant breeding. Marcel Dekker Inc., New York.

Harding, S.A., J.A. Guikema, and G.M. Paulson. 1990. Photosynthetic decline from high temperature stress during maturation of wheat. II. Interaction with source sink processes. Plant Physiol. 92:654-658. doi:10.1104/pp.92.3.654

Hardy, R.J., and S.G. Thompson. 1996. A likelihood approach to meta-analysis with random effects. Stat. Med. 15:619-629. doi:10.1002/(SICI)1097-0258(19960330)15:6<619::AIDSIM188>3.0.CO;2-A

Howden, S.M., J.F. Soussana, F.N. Tubiello, N. Chhetri, M. Dunlop, and H. Meinke. 2007. Adapting agriculture to climate change. Proc. Natl. Acad. Sci. USA 104:19691-19696. doi:10.1073/pnas.0701890104

Howarth, C.J. 2005. Genetic improvements of tolerance to high temperature. In M. Ashraf and P.J.C. Harris (ed.) Abiotic stresses: Plant resistance through breeding and molecular approaches. Howarth Press, New York.

Huang, B., and H. Gao. 2000. Growth and carbohydrate metabolism of creeping bent grass cultivars in response to increasing temperatures. Crop Sci. 40:1115-1120. doi:10.2135/ cropsci2000.4041115x

IBPGR. ICRISAT, and ICARDA. 1993. Descriptors for chickpea (Cicer arietinum L.). International Board for Plant Genetic Resources, Rome, Italy; International Crops Research Institute for the Semi-Arid Tropics, Patancheru, India, and International Center for Agriculture Research in the Dry Areas, Aleppo, Syria.

Johansen, C., D.N. Singh, L. Krishnamurthy, N.P. Saxena, Y.S. Chauhan, and J.V.D.K. Kumar Rao. 1997. Options for alleviating moisture stress in pulse crops. p. 425-442. In A.N. Asthana and Masood Ali (ed.) Recent advances in pulses research. Indian Society of Pulses Research, IIPR, ISPR, Kanpur, India.

Kinet, J.M., and M.M. Peet. 1997. Tomato. p. 207-258. In H.C. Wien (ed.) The physiology of vegetable crops. CAB International, Wallingford, UK.

Kumar, J., and van Rheenan. 2000. A major gene for flowering in chickpea. J. Hered. 91:67-68. doi:10.1093/jhered/91.1.67

Kelly, T.G., and P.R. Parthasarathy. 1994. Chickpea competitiveness in India. Econ. Polit. Wkly. 29:89-100.

Nielsen, C.L., and A.E. Hall. 1985a. Responses of cowpea (Vigna unguiculata [L.] Walp.) in the field to high night temperature during flowering: I. Thermal regimes of production regions and field experimental system. Field Crops Res. 10:167-179. doi:10.1016/0378-4290(85)90024-3

Nielsen, C.L., and A.E. Hall. 1985b. Responses of cowpea (Vigna unguiculata [L.] Walp.) in the field to high night temperatures during flowering: II. Plant responses. Field Crops Res. 10:181-196. doi:10.1016/0378-4290(85)90025-5

Ozkan, H., I. Genc, T. Yagbasalnar, and F. Toklu. 1999. Stress tolerance in hexaploid spring triticale under Mediterranean environment. Plant Breed. 118:365-367. doi:10.1046/j.14390523.1999.00396.x

Patterson, H.D., and R. Thompson. 1971. Recovery of interblock information when block sizes are unequal. Biometrika 58:545-554. doi:10.1093/biomet/58.3.545

Schönfeld, P., and H.J. Werner. 1986. Beiträgr zur teorie undanwendung linearer modelle. p. 251-262. In W. Krelle (ed.) 
ökonomische progress-, entscheidungsund gleichgewichtsmodelle. VCH Verlagsgesellschaft, Weinheim, Germany.

Siddique, K.H.M., S.P. Loss, K.L. Regan, and R.L. Jettner. 1999. Adaptation and seed yield of cool season grain legumes in Mediterranean environments of south-western Australia. Aust. J. Agric. Res. 50:375-387. doi:10.1071/A98096

Sharma, D., and N.S. Jodha. 1984. Constraints and opportunities of pulse production in semi-arid regions of India. p. 241-265. In H.C. Srivastava et al. (ed.) Pulses production constraints and opportunities: Proceedings of symposium on increasing pulse production in India-constraints and opportunities. Oxford and IBH Pub. Co., New Delhi.

Stone, P. 2001. The effects of heat stress on cereal yield and quality. p. 243-291. In A.S. Basra (ed.) Crop responses and adaptation to temperature stress. Food Products Press, Binghamton, NY.

Subbarao, G.V., C. Johansen, A.F. Slinkard, R.C. Nageswara Rao, N.P. Saxena, and Y.S. Chauhan. 1995. Strategies for improving drought resistance in grain legumes. Crit. Rev. Plant Sci. 14:469-523.

Toker, C., and S.S. Yadav. 2010. Legumes cultivars for stress environments. p. 351-376. In S.S. Yadav and R. Redden (ed.) Climate change and management of cool season grain legume crops. Springer, the Netherlands.

Travasso, M.I., G.O. Magrin, W.E. Baethgen, J.P. Castano, G.R. Rodriguez, J.L. Pires, A. Gimenez, G. Cunha, and M. Fernandes. 2006. Working Paper No. 28, Assessments of impacts and adaptations to climate change [Online]. Available at www.aiaccproject.org/working_papers/working_papers. html (verified 7 June 2011). AIACC, Washington, DC.

Upadhyaya, H.D., P.J. Bramel, and S. Singh. 2001. Development of a chickpea core subset using geographic distribution and quantitative traits. Crop Sci. 41:206-210. doi:10.2135/ cropsci2001.411206x

Wahid, A., S. Gelani, M. Asraf, and M.R. Foolad. 2007. Heat tolerance in plants: An overview. Environ. Exp. Bot. 61:199223. doi:10.1016/j.envexpbot.2007.05.011

Wald, A. 1943. Test of statistical hypotheses concerning several parameters when the number of observations is large. Trans. Am. Math. Soc. 54:426-482. doi:10.1090/S0002-9947-1943-0012401-3

Warrag, M.O.A., and A.E. Hall. 1983. Reproductive response of cowpea to heat stress: Genotypic differences in tolerance to heat at flowering. Crop Sci. 23:1088-1092. doi:10.2135/crops ci1983.0011183X002300060016x

Whitehead, A. 2002. Meta-analysis of controlled clinical trials. Wiley, Chichester, UK.

Wien, H.C., and E.E. Ackah. 1978. Pod development period in cowpeas: Varietal differences as related to seed characters and environmental effects. Crop Sci. 18:791-794. doi:10.2135/cro psci1978.0011183X001800050026x

Williams, P.C., and U. Singh. 1987. Nutritional quality and the evaluation of quality in breeding programmes. p. 329-356. In M.C. Saxena and K.B. Singh (ed.) The chickpea. CAB International, Wallingford, UK.

Wu, L., and D.R. Huff. 1983. Characteristics of creeping bent grass clones (Agrostis stolonifera L.) from a salinity-tolerant population after surviving drought stress. HortScience 18:883-885.

$\mathrm{Xu}$, Q., and B. Huang. 2001. Morphological and physiological characteristics associated with heat tolerance in creeping bent grass. Crop Sci. 41:127-133. doi:10.2135/cropsci2001.411127x 